\title{
Late Holocene environmental change in Lake Boquete and its watershed: human or natural causes?
}

\author{
Yunuén Temoltzin-Loranca, María Isabel Velez, Enrique Moreno, Jaime Escobar
}

\begin{abstract}
Yunuén Temoltzin-Loranca
ytl@uregina.ca

María Isabel Velez

Department of Geology, University of Regina, 3737 Wascana Parkway, Regina, SK S4S0A2, Canada.

\section{Enrique Moreno \\ Jaime Escobar \\ Smithsonian Tropical Research Institute (STRI), Center for Tropical Paleoecology and Anthropology (CTPA), Gorgas St., Bldg. 235, Balboa, Ancon, Panama, Republic of Panama.}

\section{Jaime Escobar}

Institute for Sustainable Development, Universidad del Norte, Km. 5 Vía Puerto, Colombia.

BOL. SOC. GEOL. MEX. 2018

VOL. 70 NO. 1

P. $121-131$

http://dx.doi.org/10.18268/BSGM2018v70nla7

\begin{abstract}
A paleolimnological and environmental reconstruction of the volcanic Lake Boquete, in the northern highlands of Panama, was produced based on diatom, sediment, and charcoal analyses. The main aim of this study is to contribute to the understanding of the long-term anthropogenic effect in Lake Boquete and its watershed, a unique space (Gran Chiriqui region) where human occupation and nature have interacted since $\sim 7000$ yr BP (years Before Present). Our results indicate two main periods of environmental change. In the first period, from $\sim 2840$ to 1740 cal yr BP (calibrated years Before Present), the lake was under the influence of high-energy flow regimes and high erosion rates. Water $\mathrm{pH}$ was gradually changing from neutral to alkaline. There's evidence of fires with four main events, some appear to be natural as indicated by the proxies, while others seem to be associated with anthropic causes most likely related to intense periods of cultivation; a particularly intense fire event is identified at $\sim 2607 \mathrm{cal} \mathrm{yr}$ BP. We infer that during this period the lake and its watershed were under intense human impact. In the second period, from $\sim 1740$ to $197 \mathrm{cal}$ yr BP, the lake was under a steady low-energy flow regime, submerged vegetation was more abundant, and $\mathrm{pH}$ became more acidic, fire events were less frequent. We infer that these conditions were the result of land abandonment due to human migration to the lowlands. Notwithstanding intense and frequent dry climate spells during the second period, Lake Boquete water levels were not affected, and thus, this record suggest that the main cause of environmental and limnological change in Lake Boquete and its watershed has been anthropogenic activities.
\end{abstract}

Keywords: Paleolimnology, late Holocene, diatoms, charcoal, sediment, Panama.

\section{RESUMEN}

Este trabajo consiste en una reconstrucción paleolimnológica y ambiental de la Laguna Boquete, ubicada en las tierras altas del Norte de Panamá, dicha reconstrucción se hizo mediante análisis de diatomeas, sedimento y carbón. El propósito de este estudio es contribuir al entendimiento del efecto antropogénico en la laguna Boquete y su cuenca, un lugar único (región del desarrollo de La Gran Chiriquí) donde la naturaleza y los humanos han interactuado desde 7000 años A.P. (Antes del Presente). Nuestros resultados indican dos principales periodos de cambio ambiental. En el primer periodo comprendido del $\sim 2840$ al 1740 años cal AP la laguna estuvo bajo la influencia de altos niveles de energía de transporte de sedimentos, tasas de erosión elevadas, y el pH en la columna de agua fue cambiando gradualmente de neutro a alcalino. Los incendios fueron constantes durante todo el periodo, con 4 eventos significativos, algunos provocados por causas naturales y otros por acciones antropogénicas, estos últimos relacionados con periodos intensos de agricultura. Un evento de fuego fue registrado 2607 años cal A.P. Durante este primer periodo, se infiere que la laguna y su cuenca estuvieron siendo impactadas por actividades humanas.

En el segundo periodo de 1740 al 197 años cal A.P., la laguna se mantuvo en condiciones calmadas con un flujo de energía bajo (comparado al primer periodo), la vegetación fue más abundante y el pH tendió a ser más ácido; los eventos de fuego fueron menos frecuentes. Se infirió que estas condiciones fueron el resultado del abandonamiento de algunas tierras a causa de migraciones humanas hacia las tierras bajas.

A pesar de los intensos y frecuentes episodios de clima seco durante el segundo periodo, los niveles de agua en la laguna Boquete no fueron afectados y por lo tanto, este registro sugiere que la principal causa del cambio ambiental y limnológico en el lago Boquete y su cuenca han sido las actividades antropogénicas.

Palabras clave: Paleolimnología, Holoceno tardío, diatomeas, carbón, sedimento, Panamá. 


\section{Introduction}

The Anthropocene has been considered the geologic time period in which humans and their activities have become a global geophysical force, noticeable since 1800 CE (Steffen et al., 2007). However, it is clear that human activities have been affecting ecosystems and environments since the Neolithic (Ruddiman, 2014) in which fire was used to clear forests for cultivation (Dietre et al., 2017). It is still a matter of debate to identify the exact time and stratigraphic interval for the start of the Anthropocene, Steffen et al. (2007) reported the first evidences of the Anthropocene from 8000 to $5000 \mathrm{yr}$ BP while Lewis and Maslin (2015) stated that it is difficult to say when this epoch started because there is not an agreement in respect to a reference point.

There is several studies that evaluate changes in the Anthropocene, for instance, the record from El Valle (Bush and Colinvaux, 1990), shows the responses of terrestrial ecosystems to variations in precipitation, while the records from La Yeguada (Piperno et al., 1991) and Monte Oscuro (Piperno and Jones, 2003) illustrate that human populations have played an important role in shaping terrestrial ecosystems in Panama since 11000 yr BP.

A record from El Darien, on the other hand (Bush and Colinvaux, 1994), indicated that El Niño Southern Oscillation (ENSO) was not linked to major impacts on the aquatic ecosystem in this region. However, all the records mentioned above are from the midland and lowland areas and are mainly based on pollen and phytolith analyses. The recent record from San Carlos (Correa-Metrio et al., 2016) has been the only one so far, from Panamanian middle elevations and the only one that has studied the evolution and dynamics of the aquatic-terrestrial ecosystem using a multiproxy approach. Thus, very little is known about environmental change in the highlands from Panama, and more records are necessary to understand the anthropogenic effect in natural systems. Paleorecords in the tropics have shown that climatic phenomena can vary and affect different regions in different ways, across the stretch of land and also in a vertical dimension (Bush and Colinvaux, 1994; Leyden, 1995; Behling, 2000). Thus, dissociating from human and natural signals in climatic paleorecords in this region has significant challenges.

We analyzed diatoms, charcoal, and sediments from a core taken from Lake Boquete on March 13, 1996. This core was collected as part of a project led by Paul A. Colinvaux and Enrique Moreno, where a census of the lakes in Panama was made, as a first step towards the study of the Panama Quaternary flora after the last ice age. This project was part of one of the three global programs PEP (Pole-Equator-Pole) in which "PEP-1" was the transect for the Americas. Although this core was collected in 1996, it was not studied until 2010, when Holmberg (2009, 2010, 2016) analyzed the tephra layers to explore their potential as a tool for archaeological dating.

The main aim of the present study is to contribute to the understanding of the long term anthropogenic effect in highland Lake Boquete and its watershed, a unique space where human occupation started 7000 yr BP (García-Jordán, 1996; Palumbo, 2009).

\subsection{ARGHEOLOGY OF THE STUDY AREA}

Archeological studies, indicate that the Gran Chiriquí region was settled in Southern Costa Rica and Northern Panama (in the area surrounding the volcan) o since the mid-Holocene (Haberland, 1984; Palumbo, 2009). Three main cultural periods have been recognized: (I) Archaic or Pre-Ceramic $(6950$ - 2450 yr BP), (II) Formative (2450 - 1350/1250 yr BP), and (III) Precontact (1250 430 yr BP) (Drolet, 1988). During the Archaic, the population was mainly composed of hunter-gatherers, but between 4250 and 3950 yr BP, a new archeological phase known as the Boquete phase is identified by the appearance of more efficient tools used in deforestation and agriculture (of mainly tubercles and corn). During the Formative period, social organization saw the progress of chiefdoms and the onset of human migration, mainly from 
the highlands to the lowlands; food was mainly based on corn and manioc, accompanied by products from fishing and hunting. At $1350 \mathrm{cal} \mathrm{yr} \mathrm{BP}$ (calibrated years Before Present), an important city known as Barriles, located in northwest Chiriquí, was abandoned, but the reason remains unclear, Linares (1977) argues that Barriles was abandoned due to a volcanic eruption from Barú, while Snarskis (1985) suggests it was related to the invasion of the site probably by Kuna groups coming from Colombia. At the end of the Formative and during the Precontact period, Hoopes (1996) identified a cultural phase known as Bugaba (1350 - 150 yr $\mathrm{BP})$, which belongs to the Aguas Blancas period, during which sedentary populations appeared.

During the Precontact period, centers of different specialization (e.g. agriculture, pottery, elaboration of lithic tools) appeared for the first time and human migration towards these centers continued.

\section{Study area}

Lake Boquete is located at $8^{\circ} 52^{\prime} 50.49^{\prime \prime} \mathrm{N}$, $82^{\circ} 29^{\prime} 47.96^{\prime \prime} \mathrm{W}$ in the Talamanca Mountain Range, within the boundaries of Bocas del Toro and Chiriquí provinces, Panama, at an altitude of 2116 m.a.s.l. The lake is located $9 \mathrm{~km}$ northeast of Barú Volcano (Figure 1), its maximum depth is 12 $\mathrm{m}$. Since the lake lacks an official name, we use the name that Colinvaux used in the past.

The climate of the area is influenced by the Atlantic Ocean and modulated by different factors such as topography, subsidence, the cyclic migration of the Intertropical Convergence Zone (ITCZ), and the trade winds that lead to the Central American Monsoon (Giannini et al., 2000). Other phenomena, such as ENSO, change precipitation rates and the length of seasonality in tropical regions, including Panama (Lachniet et al., 2004). The nearest meteorological station in Bocas del Toro province, reports a mean annual temperature of $\sim 14.7^{\circ} \mathrm{C}$ and yearly rainfall of $\sim 2650 \mathrm{~mm}$ (Contraloría Panama, 2003).

\section{Methodology}

Sediment cores of Lake Boquete were taken with a Livingstone piston sampler in $1 \mathrm{~m}$ long and 60 $\mathrm{mm}$ diameter aluminum tubes. Three vertical cores were obtained from the deepest part of the lake $(\sim 12 \mathrm{~m})$ and transferred to the laboratory where they were stored at $4{ }^{\circ} \mathrm{C}$. The core was then sampled for radiocarbon dating, diatom counting and identification, charcoal analyses, and sediment description. Three samples of organic sediment were taken from the core for radiocarbon dating, pretreated with acid washes, and sent to Beta Analytic for analysis in October, 1996.

Radiocarbon dates (Table 1) were calibrated using IntCal13 calibration curve (Reimer et al., 2013) and an age model (Figure 2a) was obtained through Bacon (Blaauw and Christen, 2011). Diatoms were sampled every $5 \mathrm{~cm}$ and prepared according to the methodology of Battarbee (1986). Diatom slides were mounted using $\operatorname{Zrax}^{\circledR}(\mathrm{RI} \sim$ $1.7^{+}$), and at least 400 valves were counted for each sample using an Olympus CX41 microscope at $1000 \times$ magnification. Diatom diagram and cluster analysis were carried out using Tilia Graph and the CONISS program in Tilia (Grimm, 1987, 1992).

For charcoal analysis, sediment samples of $0,25 \mathrm{~cm}^{3}$ were extracted from the core, deflocculated with sodium pyrophosphate $\left(\mathrm{Na}_{4} \mathrm{P}_{2} \mathrm{O}_{7} \cdot 10 \mathrm{H}_{2} \mathrm{O}\right)$ solution (ca. $10 \%$ ) and separated under a stereomicroscope according to the methodology proposed by Clark (1988). Particles were analyzed with Imagef (Rasband, 1997). Different sizes of charcoal were directly correlated to distance of transport; i.e., the greater the distance, the smaller the particle size, and vice versa. Considering the longest axis, particles $>100 \mu \mathrm{m}$ indicated that the fire events were local, and particles $<100 \mu \mathrm{m}$ suggested regional or non-local fires (Withlock and Larsen, 2001). In cases of having charcoal samples, with particle sizes of the two groups mentioned above, the occurrence of two or more simultaneous fire events is assumed (Patterson et al., 1987). 

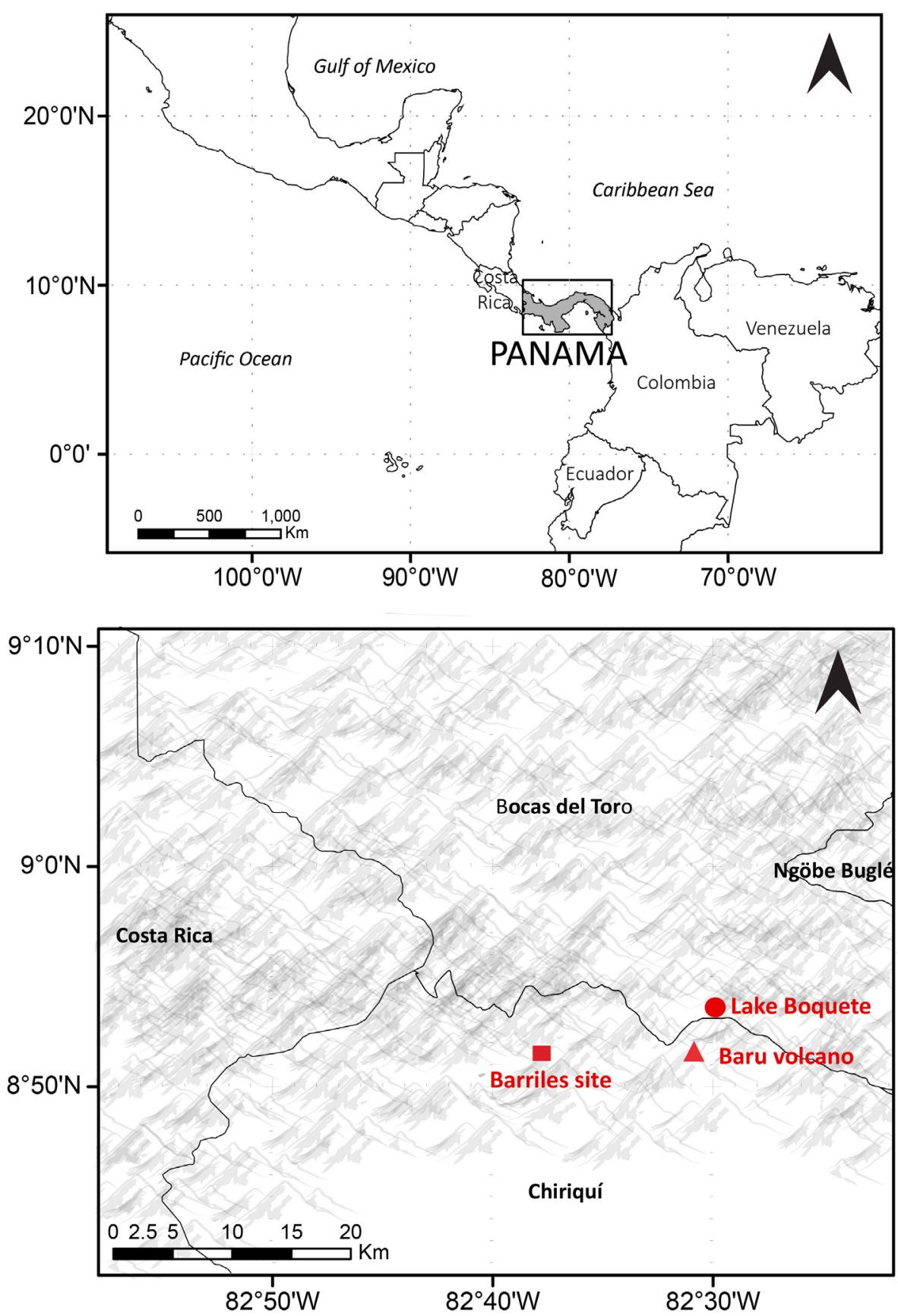

Figure 1 Study Area. (Above) Panama within Central America. (Below) Location of Lake Boquete.

Table 1. Radiocarbon dates from the core of Lake Boquete.

\begin{tabular}{|c|c|c|c|c|}
\hline Lab ID & $\begin{array}{c}\text { Age } \\
\left(\mathbf{C}^{\mathbf{1 4}}\right)\end{array}$ & $\begin{array}{c}\text { Error } \\
(\mathbf{y r s})\end{array}$ & $\begin{array}{c}\text { Depth } \\
(\mathbf{c m})\end{array}$ & $\begin{array}{c}\text { Age } \\
\text { (Cal yr BP) }\end{array}$ \\
\hline Beta95701 & 1400 & \pm 60 & 17 & 409.6 \\
\hline Beta95702 & 2050 & \pm 50 & 140 & 1967.2 \\
\hline Beta95703 & 2730 & \pm 60 & 236 & 2869.9 \\
\hline
\end{tabular}

A qualitative description of the sediment and organic matter content was done using a stereomicroscope. Sediment grain size was classified according to the grain size chart of Stow (2005) by analyzing the shape, roundness and sphericity of particles. Organic matter was counted as a percentage in each sample. 


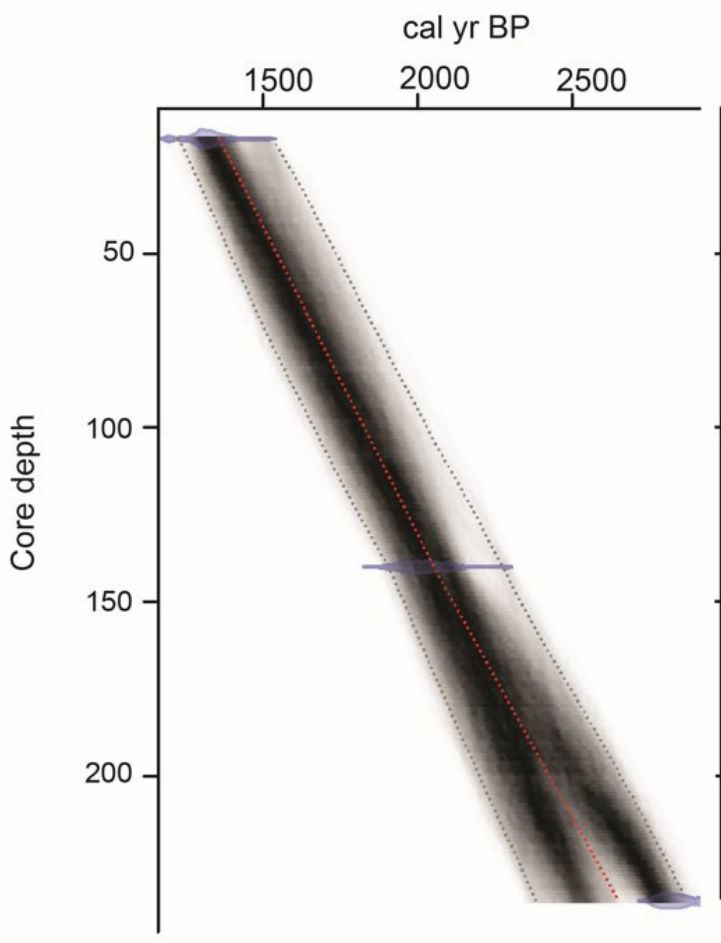

(a)
Accumulation rates $(\mathrm{cm} / 5 \mathrm{yr})$

$\begin{array}{lllllll}0.1 & 0.2 & 0.3 & 0.4 & 0.5 & 0.6 & 0.7\end{array}$

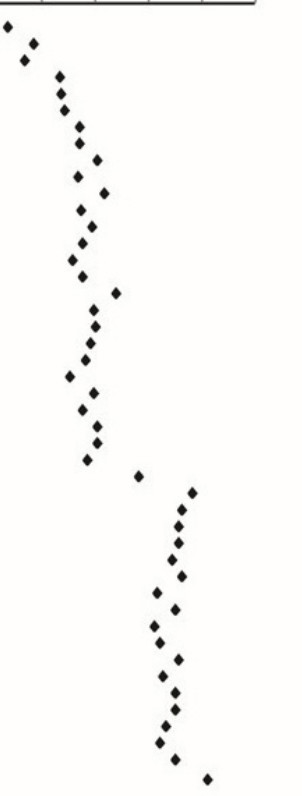

(b)

Figure 2 Age model (a) and accumulation rates (b) of the core from Lake Boquete.

\section{Results}

The age model shows that the base of the core is 2840 cal yr BP (Figure 2a). Sediment accumulation rates $(\mathrm{cm} / 5 \mathrm{yr})$ were obtained through Bacon; these show a gradual decrease from base values of $0.5-0.6 \mathrm{~cm} / 5 \mathrm{yr}$ to top values of $0.3-0.2 \mathrm{~cm} / 5$ yr (Figure 2b).

The sediment composition is mainly silt, with varying amounts of clay, sand, and organic matter (Figure 3). From 235 to $100 \mathrm{~cm}$, the sediment is composed mainly of silt with relatively low organic content $(5-20 \%)$. Sand content is moderate to abundant. From 100 to $5 \mathrm{~cm}$, the grain size decreases and the sediment is composed of silt, clay, and minor abundance of sand. The organic matter increased considerably with maxima of $50 \%$. A distinct tephra layer is present at $15 \mathrm{~cm}$ (Figure 3). Reworked tephra is observed at 107, 102, 92, 87,7 , and $5 \mathrm{~cm}$.
The highest concentrations of charcoal are recorded between 218 and $158 \mathrm{~cm}$ with a peak of $75.2 \mathrm{~mm}^{2} / \mathrm{cm}^{3}$ at $208 \mathrm{~cm}$. From 158 to $5 \mathrm{~cm}$ some minor increases occurred at 127, 112, 81, 76, 71, 41 , and $26 \mathrm{~cm}$, with concentrations of $9.87,8.99$, $6.58,13.14,12.01,7.29$ and $5.86 \mathrm{~mm}^{2} / \mathrm{cm}^{3}$, respectively. At the charcoal peak at $208 \mathrm{~cm}$, we found variation in sizes of charcoal, as approximately $70 \%$ of particles were less than $0.01 \mathrm{~mm}$ in its longest side. However, there are also larger particles, about $1 \mathrm{~mm}$, being the greatest particle $3.6 \mathrm{~mm}$, indicating a possible fire event close to Lake Boquete.

Diatom analysis (Figure 3) shows that the core is dominated by benthic species, with small amounts of planktic species (less than $3 \%$ ). Benthic species are dominated by Encyonema evergladianum (Krammer, 1997), and Gomphoema gracile (Ehrenberg, 1838). Planktic species include Aulacoseira granulata (Simonsen, 1979), and Dicostella stelligera (Houk and Klee, 2004). Other benthic species common throughout the core include Pinnularia acrosphaeria 

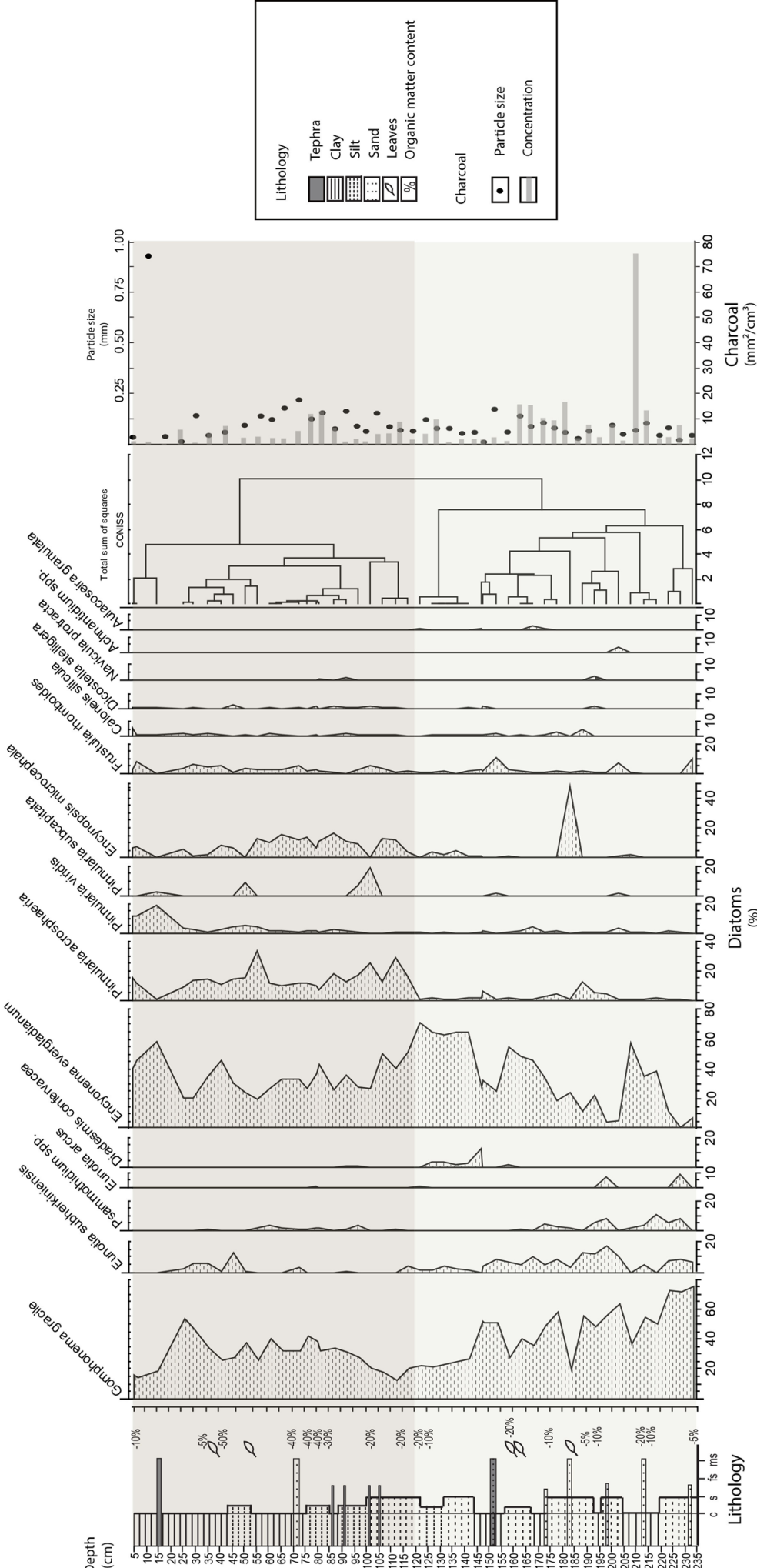
(Krammer and Lange-Bertalot, 1986), Encynopsis microcephala (Krammer, 1997), Eunotia subherkiniensis (Krammer and Lange-Bertalot, 1991), Frustulia rhomboides (De Toni, 1891), and Caloneis silicula (Krammer and Lange-Bertalot, 1986). The dominance of benthic species throughout the core suggests a relatively stable lake bottom. Two main zones were identified after a visual inspection of the core and from CONISS analysis:

1. From 235 to $120 \mathrm{~cm}$, G. gracile dominates (average $45 \%$ ), and has a decreasing trend towards the top of the zone whereas E. evergladianum (average $34 \%$ ) shows an opposite trend with its representation increasing towards $120 \mathrm{~cm}$. In this zone, E. subherkiniensis and Psammothidium spp. are more abundant (averages $7 \%$ and $3 \%$, respectively). Diadesmis confervacea has its main appearance (average $4 \%$ ) between 150 and $130 \mathrm{~cm}$.

2. From 120 to $5 \mathrm{~cm}$ depth, E. evergladianum and G. gracile still dominate (averages $37 \%$ and 29 $\%$, respectively), but Pinnularia acrosphaeria and Encyonopsis microcephala become more abundant $(14 \%$ and $8 \%$, respectively). P. viridis and $P$. subcapitata increase in this zone (averages of $4 \%$ and $2 \%$, respectively).

\section{Paleoenvironmental interpretation}

The diatom assemblages from this core (Figure 3) suggest that for most of the time, the lake maintained clear waters with low nutrient concentrations and a changing $\mathrm{pH}$ from neutral to more basic, as indicated by the ecology of the dominant diatoms (Moro and Furestenberger, 1997). From 2840 to $1740 \mathrm{cal}$ yr BP (Zone 1) the dominance of benthic epiphytic species E. evergladianum and $G$. gracile indicates a stable lake bottom most possibly colonized by macrophytes. The high abundance of epipelic Psammothidium spp. (Spaulding and Edlund, 2008) and aerophil species E. subherkiniensis (Lange-Bertalot, 2011) and D. confervacea (Carvalho and Dos Santos, 2008) suggests influence of littoral environments. E. evergladianum and $G$. gracile indicate that the $\mathrm{pH}$ was neutral; however, the appearance of $P$. acrosphaeria might be indicative of increased alkalinity towards the end of the period. Although planktic species are rare, A. granulata occurs in a few samples. This might be indicative of changes in turbulence.

From 1740 cal yr BP to present (Zone 2), conditions similar to Zone 1 are maintained as suggested by the dominant diatoms. However, it is possible that a decrease in $\mathrm{pH}$ toward acidic values occurred as suggested by the increase of Pinnularia spp, Eunotia spp, and E. microcephala. The marked increase in periphytic $E$. microcephala most likely indicates an increase in the littoral and/or in submerged vegetation; this is also supported by the increase of plant remains preserved in the sediment. The abundance of planktonic D. stelligera during this period could be indicative of periods of higher water levels and an increase in nutrients (Costa-Böddeker et al., 2012).

At $1490 \mathrm{cal}$ yr BP $(100 \mathrm{~cm})$, the sediment grain size changes from generally coarser sand and silt below to finer silt and clay above (Figure 3). After this time, the organic matter increases overall, with up to $50 \%$ content in some samples. In general, accumulation rates decrease, suggesting a change from higher to lower hydrologic energy, and possibly less erosion. There was also an increase in plant remains in the sediment indicative of more abundant vegetation. A volcanic event, most likely from Barú volcano, is recorded in our core at $\sim 379$ cal yr BP $(15 \mathrm{~cm})$. This event could be correlated with the Barú eruption dated at $\sim 1550$ AD reported by the Global Volcanism Program (2013), and with the tephra layers reported by Holmberg (2010). This date also works as an independent age for our core, which validates the dates and age model obtained by Bacon.

The high abundance and great variability in charcoal sizes recorded at $2610 \mathrm{cal}$ yr BP $(208 \mathrm{~cm})$ suggest that several fire events occurred around this time. The period from 2327 to $2140 \mathrm{cal} \mathrm{yr} \mathrm{BP} \mathrm{(178}$ $-158 \mathrm{~cm}$ ) seems to have been a period of frequent fires. After this time, fire frequency decreased.

The change in the diatom assemblages recorded 
at $\sim 1740$ cal yr BP predates the changes in lithology (grain size and organic matter content) and in sediment accumulation rates observed at $\sim 1466$. These changes, as well as the increase in water $\mathrm{pH}$ and in vegetation, suggest a switch in the system to quieter depositional conditions and less frequent fires.

\section{Discussion and concluding remarks}

The record obtained from Lake Boquete shows that a marked change in the surrounding environment occurred between 1740 and 1466 cal yr BP, correlated with the end of the Formative period. We hypothesize that coarser grain sizes, higher accumulation rates, and lower content of organic matter in the sediments recorded between 2840 and $1740 \mathrm{cal}$ yr BP reflect erosion in the watershed, most likely as a by-product of deforestation. The change to finer grain sizes, lower accumulation rates, and higher content of organic matter recorded after $1740 \mathrm{cal}$ yr BP reflect less erosion as a result of a stable soil cover by vegetation. The period before $1740 \mathrm{cal}$ yr $\mathrm{BP}$ correlates with the Formative period of the Gran Chiriquí culture that witnessed an increase in efficiency of agricultural practices and corn cultivation, as a result of the need to feed a growing population now organized in bigger centers (Palumbo, 2009). Thus, Zone 1 in our record reflects this period of demographic increase and agricultural development. Meanwhile Zone 2, correlates with the end of the Formative, when human migration from the highlands to the lowlands became more pronounced and agricultural practices in the highlands decreased.

According to Taylor (2011) the peak in agriculture occurred from about 1718 yr BP to 1400 yr BP. After this time it began to decline (Taylor et al., 2013) and by 850 yr BP it had ceased completely. As a result of agricultural abandonment, forests recovered (Taylor 2011), erosion decreased, and more stable conditions prevailed as inferred from period 2 of our record. It is suggested then, that from 2840 to $1740 \mathrm{cal} \mathrm{yr} \mathrm{BP}$ the lake's watershed was under intense anthropogenic activities including deforestation and cultivation, and that after $1740 \mathrm{cal}$ yr BP anthropogenic activities decreased and a stable vegetation cover developed. The increase in organic matter arriving to the lake originated from the abundant vegetation, and could have been the cause of the more acidic waters inferred in period 2 .

It is also important to consider the climatic scenario during these periods. At around $1400 \mathrm{yr}$ BP important changes in precipitation affected Panama (Lachniet et al., 2004). These include a dry period attributed to an intense "El Niño" event at 1300 yr BP (Linares et al., 1975), and another dry period between 1050 and $640 \mathrm{yr}$ BP (Lachniet et al., 2004) or from 1180 to $940 \mathrm{yr} \mathrm{BP}$ according to Webster (2002). The charcoal and diatom records show that these intense and frequent dry conditions did not affect Lake Boquete and its watershed, and thus our record suggest that the main stressors to the lake have not been the natural phenomena but anthropic activities.

\section{Acknowledgements}

We thank in memoriam Dr. P.A. Colinvaux, Smithsonian Tropical Research Institute, Panama for coring and providing the samples. We also thank Dr. Karen Holmberg for her information about Lake Boquete. Financial support came from the Inter-American Institute for Global Change Research (IAI, grant number CRN3038), the US National Science Foundation (Grant GEO-1 128040), and the University of Regina start-up funds to $\mathrm{M}$. Vélez.

\section{References}

Battarbee, R., 1986, Diatom analysis, in Berglund, B.E. (ed.), Handbook of Holocene palaeoecology and palaeohydrology: Chichester, John Wiley and Sons, 527-570. 
Behling, H., 2000, A 2860-year high-resolution pollen and charcoal record from the Cordillera de Talamanca in Panama: a history of human and volcanic forest disturbance: The Holocene, 10(3), 387-393.

Blaauw, M., Christen, J., 2011, Flexible paleoclimate age-depth models using an autoregressive gamma process: Bayesian Analysis, 6(3), 457-474.

Bush, M.B., Colinvaux, P.A., 1990, A pollen record of a complete glacial cycle from lowland Panama: Journal of Vegetation Science, 1(1), 105-118.

Bush, M.B., Colinvaux, P.A., 1994, Tropical forest disturbance: Paleoecological records from Darien, Panama, Ecology, 75(6), 1761-1768.

Carvalho, T.L., Dos Santos, C.B., 2008, Diadesmis confervacea (DiadesmiaceaeBacillariophyta): Morfología externa, distribucão e aspectos ecológicos, Iheringia, Série Botánica, 1(63), 171-176.

Clark, J.S., 1988, Particle motion and the theory of charcoal analysis: source area, transport, deposition, and sampling: Quaternary Research, 30, 6780.

Contraloría Panamá, 2003, Precipitación anual y máxima mensual registradas en las estaciones meteorológicas de la República (online): Instituto Nacional de Estadística y Censo, available at <https://www.contraloria. gob.pa/inec/archivos/P3771121-03.pdf>, retrieved September 28, 2016.

Correa-Metrio, A., Vélez, M., Escobar, J., StJacques, J.M., López-Pérez, M., Curtis, J., Cosford, J., 2016, Mid-elevation ecosystems of Panama: future uncertainties in light of past global climatic variability: Journal of Quaternary Science, 31(7), 731-740.

Costa-Böddeker, S., Bennion, H., Jesus, T., Albuquerque, A., Figueira, R., Bicudo, D., 2012, Paleolimnologically inferred eutrophication of a shallow, tropical, urban reservoir in southeast Brazil: Journal of Paleolimnology, 48(4), 751-766.
De Toni, G.B., 1891, Sylloge algarum omnium hucusque cognitarum, Sylloge Bacillariearum, 2, Padua: Sumptibus auctoris Typis Seminarii, 1-490.

Dietre, B.,Walser, C., Kofler, W., Kothieringer, K., Hajdas I., Lambers, K., Reitmaier, T., Haas, J.N., 2017, Neolithic to Bronze Age (4850$3450 \mathrm{cal}$. BP) fire management of the Alpine Lower Engadine landscape (Switzerland) to establish pastures and cereal fields: The Holocene, 27(2), 181-196.

Drolet, R., 1988, The emergence and Intensification of complex societies in Pacific Southern Costa Rica, in Lange, F. (ed.), Costa Rican Art and Archaeology: essays in honor of Frederick R. Mayer: Boulder, The University of Colorado Press, 163-188.

Ehrenberg, C.G., 1838, Die Infusionsthierchen als vollkommene Organismen: Ein Blick in das tiefere organische Leben der Natur: Leipzig: Verlag von Leopold Voss, 1-18.

García-Jordán, P., 1996, Las raíces de la memoria: América Latina, ayer y hoy, quinto encuentro debate: Barcelona, España, Editions Universitat Barcelona, 203-220.

Giannini, A., Kushnir, Y., Cane, M., 2000, Interannual Variability of Caribbean Rainfall, ENSO, and the Atlantic Ocean: Journal of Climate, 13(2), 297-311.

Grimm, E., 1987, CONISS: A FORTRAN 77 program for stratigraphically constrained cluster analysis by the method of the incremental sum squares: Computers and Geoscience 13, 3-13.

Grimm, E., 1992, Tilia and Tilia-graph: pollen spreadsheet and graphics programs, 8th International Palynological Congress, Aix en Provence, France, 56 p.

Haberland, W., 1984, The archaeology of Greater Chiriqui, in Lange F., Stone, D. (ed.), The archaeology of lower Central America: Albuquerque, University of New Mexico Press, 233-253. 
Holmberg, K., 2009, Nature, material, culture, and the volcano: The archaeology of the Volcán Barú in Highland Chiriquí, Panamá: United States, Columbia University, $\mathrm{PhD}$ dissertation, $507 \mathrm{p}$.

Holmberg, K., 2010, The conceptual "mapping" of a volcano in its social landscape: volcán Barú, Panamá, in Grattan, J., Torrence, R. (eds.), Living Under the Shadow, Cultural Impacts of Volcanic Eruptions: United States, Left Coast Press, 275-285.

Holmberg, K., 2016, The cultural nature of tephra: 'Problematic' ecofacts and artifacts and the Barú volcano, Panama: Quaternary International, 394, 133-151.

Hoopes, J., 1996, Settlement, subsistence, and the origins of social complexity in Greater Chiriquí: a reappraisal of the Aguas Buenas tradition, in Lange, F. (ed.), Paths to Central American Prehistory: Boulder, Colorado: University Press of Colorado, 15-47.

Houk, V., Klee, R., 2004, The stelligeroid taxa of the genus Cyclotella (Kützing) Brébisson (Bacillariophyceae) and their transfer to the new genus Discostella gen. nov.: Diatom Research, 19(2), 203-228.

Krammer, K., 1997, Die cymbelloiden Diatomeen. Eine Monographie der weltweit bekannten Taxa Teil 2. Encyonema part., Encyonopsis and Cymbellopsis: Bibliotheca Diatomologica, 37, 1-469.

Krammer, K., Lange-Bertalot, H., 1986, Bacillariophyceae. 1. Teil: Naviculaceae, in Ettl, H., Gerloff J., Heynig H., Mollenhauer D. (Eds.), Susswasserflora von Mitteleuropa, Band 2/1: Jena, Germany, Gustav Fisher Verlag, 1-876.

Krammer, K., Lange-Bertalot, H., 1991, Bacillariophyceae. 3. Teil: Centrales, Fragilariaceae, Eunotiaceae, in Ettl, H., Gerloff,J., Heynig, H., Mollenhauer, D. (eds.), Süsswasserflora von Mitteleuropa, Band 2/3: Stuttgart, Germany, Gustav Fisher Verlag, $1-576$.
Lachniet, M., Burns, S., Piperno, D., Asmerom, Y., Polyak, V., Moy, C., Christenson, K., 2004, A 1500-year El Niño/Southern Oscillation and rainfall history for the Isthmus of Panama from speleothem calcite: Journal of Geophysical Research, 109, 1-8.

Lange-Bertalot, H., Bazk, A., Witkowski, A. 2011 , Eunotia and some related genera, in Lange-Bertalot, H. (ed.), Diatoms of Europe. Diatoms of the European Inland Water and Comparable Habitats, Vol. 6. A.R.G. Gantner, Ruggell, Liechtenstein. p. 1-747.

Lewis, S.L., Maslin, M.A., 2015, Defining the Anthropocene: Nature, 519 (7542), 171-180. Leyden, B., 1995, Evidence of the younger dryas in Central America: Quaternary Science Reviews, 14 (9), 833-839.

Linares, O., 1977, Adaptive strategies in western Panama: World Archaeology, 8(3), 304-319.

Linares, O., Sheets, P., Rosenthal, E., 1975, Prehistoric agriculture in tropical highlands: Science, 187(4172), 137-45.

Moro, R., Fürstenberger, C., 1997, Catálogo dos principais parâmetros ecológicos de diatomáceas não-marinhas: Ponta Grossa, Brazil, Universidade Estadual de Ponta Grossa, 1-282.

Palumbo, S., 2009, The Development of Complex Society in the Volcán Barú Region of Western Panama: Pittsburgh, University of Pittsburgh, $\mathrm{PhD}$ dissertation.

Patterson, W., Edwards, K., Maguire, D., 1987, Microscopic charcoal as a fossil indicator of fire, Quaternary Science Reviews, 6, 3-23.

Piperno, D., Jones, J., 2003, Paleoecological and archaeological implications of a late Pleistocene/Early holocene record of vegetation and climate from the pacific coastal plain of Panama, Quaternary Research, 59 (1), 79-87.

Piperno, D., Bush, M., Colinvaux, P., 1991, Paleoecological perspectives on human adaptation in Central Panama 1: The Pleistocene: Geoarchaeology, 6, 201-226. 
Rasband, W., 1997, ImageJ: United States, U. S. Health, available at <http://imagej.nih.gov/ ij/>, Retrieved October 2015.

Reimer, P.J., Bard, E., Bayliss, A., Beck, J.W., Blackwell, P.G., Bronk Ramsey, C., Buck, C.E., Cheng, H., Edwards, R.L., Friedrich, M., Grootes, P.M., Guilderson, T.P., Haflidason, H., Hajdas, I., Hatté, C., Heaton, T.J., Hoffmann, D.L., Hogg, A.G., Hughen, K.A., Kaiser, K.F., Kromer, B., Manning, S.W., Niu, M., Reimer, R.W., Richards, D.A., Scott, E.M., Southon, J.R., Staff, R.A., Turney, C.S.M., van der Plicht, J., 2013, IntCal13 and Marine13 Radiocarbon Age Calibration Curves 0-50,000 Years cal BP: Radiocarbon, 55, 1869-1887.

Ruddiman, W., 2014, Earth Transformed, First ed., New York: Freeman, 1-55.

Simonsen, R., 1979, The diatom system: Ideas on phylogeny, Bacillaria, 2, 9-71.

Snarskis, M., 1985, Symbolism of gold in Costa Rica and its archaeological perspective, in Mitchell, J. (ed.), The Art of Precolumbian Gold: New York, Metropolitan Museum of Art, 22-34.

Spaulding, S., Edlund, M., 2008, Psammothidium, in University of Colorado (online), Diatoms of the United States, available at <http:// westerndiatoms.colorado.edu/taxa/genus/ Psammothidium>, Retrieved in September 24, 2016.

Steffen, W., Crutzen, P., McNeill, J., 2007, The Anthropocene: Are Humans Now Overwhelming the Great Forces of Nature, AMBIO: A Journal of the Human Environment, 36(8), 614-621.

Stow, D., 2005, Sedimentary Rocks in the Field A Colour Guide: San Diego, United States, Elsevier Science Publishing, 320 p.

Taylor, Z., 2011, Spatial variation in organic carbon and stable isotope composition of lake sediments at Laguna Zoncho, Costa Rica: Knoxville, University of Tennessee, $\mathrm{PhD}$ dissertation.

Taylor, Z., Horn, S., Finkelstein, D., 2013, Maize pollen concentrations in Neotropical lake sediments as an indicator of the scale of prehistoric agriculture: The Holocene, 23(1), 78-84.

Webster, D., 2002, The Fall of the Ancient Maya: London, Thames and Hudson, $368 \mathrm{p}$.

Withlock, C., Larsen, C., 2001, Charcoal as a Fire Proxy, in. Smol, J. P, Birks H. J., Last W. M., Tracking Environmental Change Using Lake Sediments: Dordrecht, The Netherlands Kluwer Academic, 3, 75-97. 